\title{
Contribución de los entornos virtuales al aprendizaje comprensivo de las Ciencias Morfológicas
}

\author{
Benmelej, Adriana; Costamagna, Alicia; Fabro, Ana Patricia
}

\section{Resumen}

Se diseñó en la Cátedra de Morfología Normal una propuesta virtual para complementar el estudio presencial de las Ciencias Morfológicas. La misma consiste en presentar los contenidos de las asignaturas y cursos de grado y posgrado a través del "Entorno Virtual Complementario para la Enseñanza Presencial". Por medio de ella se brinda a los estudiantes un material didáctico organizado en tópicos generativos, mediante un formato con alto contenido visual. Contiene además numerosas actividades interactivas, foros de discusión y consultas electrónicas.

En cuanto a los principales resultados alcanzados por la propuesta se encuentran:

- Proporciona a los estudiantes un recurso con contenido visual que trasciende el aula.

- Anima a los estudiantes a explorar y manipular de forma activa el contenido, mediante la resolución de actividades interactivas y foros de discusión.

- Inicia o fortalece a los estudiantes en el uso de las tecnologías educativas, como herramientas para favorecer los aprendizajes y como recursos a utilizar también en otros ámbitos, por ejemplo el laboral.

- Permite a los estudiantes revisar los contenidos de las asignaturas en cualquier momento y lugar.

- Posibilita "inmortalizar" colecciones de imágenes microscópicas, que en el formato de vidrio son fácilmente deteriorables.

Actualmente se está realizando una investigación de tipo cuali-cuantitativa destinada a conocer los resultados alcanzados en relación con los aprendizajes de los estudiantes.

Palabras clave: entorno virtual, aprendizaje, ciencias morfológicas. 


\section{Sumary}

\section{Contribution of virtual environments to the comprehensive learning of morphological Sciences}

It was designed in the Department of Normal Morphology virtual proposal to supplement classroom study of Morphological Sciences. The same is to present the subject content and degree and postgraduate courses through the "Supplementary Virtual Environment for Teaching Classroom". Through it provides students were teaching materials generative topics organized by a high visual format. It also contains numerous interactive activities, discussion forums and electronic consultations. As for the main results achieved by the proposal include:

- Provides a resource for students with visual content that goes beyond the classroom.

- Encourage students to explore and actively manipulate content, by resolution of interactive activities and discussion forums.

- Starts or empowers students in the use of educational technologies as tools to enhance learning and how to use resources in other areas, such as labor. Allows students to review the course content anytime, anywhere.

- Third "immortalize" microscopic image collections, in the format that are easily perishable glass.

Keywords: virtual environment, learning-morphological sciences. 